DOI: $10.15290 /$ bsp.2019.24.04.18

Received: 05.02.2019

Accepted: 30.04 .2019

Andrzej Jackiewicz

Uniwersytet w Białymstoku

jackiewicz@uwb.edu.pl

ORCID ID: https://orcid.org/0000-0001-6957-3139

\title{
Glosa do wyroku hiszpańskiego Trybunału Konstytucyjnego z dnia 17 października 2017 r. w sprawie STC 114/2017, dotyczącej ustawy Parlamentu Katalonii o referendum o samostanowieniu ${ }^{1}$
}

Upoważnienie do zarzadzania, ale także ustanawiania przepisów regulujących konsultacje ludowe na drodze referendum, należy do ekskluzywnych kompetencji państwa.

Wszystkie przepisy konstytucji podlegaja zmianom, a suweren ma petnie władzy w zakresie dowolnego modyfikowania ich treści. Petna otwartość na rewizję oznacza także możliwość uwzględnienia takich koncepcji ideologicznych, które polegałyby na uznaniu określonej grupy za społeczność narodowa. Może się to jednak odbywać wyłacznie na drodze procedury zmiany konstytucji.

Nieprzestrzeganie przepisów regulujących postępowanie legislacyjne może prowadzić do niekonstytucyjności tak uchwalonego prawa, gdy wplynęło w znaczący sposób na proces kształtowania się woli w danej izbie, a w szczególności gdy zasady postępowania zostały potraktowane w sposób instrumentalny, naruszając zasadę pluralizmu politycznego, która jest podstawową wartością całego hiszpańskiego systemu prawnego.

1 Del Presidente del Gobierno contra la Ley del Parlamento de Cataluña 19/2017, de 6 de septiembre, denominada "del referéndum de autodeterminación", BOE nr 256, s. 102543 . Wszystkie powoływane orzeczenia dostępne również za pośrednictwem bazy hiszpańskiego Trybunału Konstytucyjnego: www.hj.tribunalconstitucional.es. 
Nie każde naruszenie procedury legislacyjnej jest podstawa uznania niekonstytucyjności danego aktu prawnego, tylko takie uchybienie, które skutkuje naruszeniami wartości konstytucyjnych ${ }^{2}$.

1. Hiszpański Trybunał Konstytucyjny (Tribunal Constitucional de España, dalej powoływany jako hiszpański akronim: TC) w przeszłości niejednokrotnie zajmował się w swoim orzecznictwie kwestią zgodności z Konstytucją Królestwa Hiszpanii (Constitución Española, dalej powoływana jako hiszpański akronim: CE) różnego rodzaju aktów normatywnych, związanych z katalońskimi dążeniami niepodległościowymi. Wyrok z dnia 17 października 2017 r. w sprawie STC 114/2017 jest kolejnym rozstrzygnięciem tego sądu, wieńczącym dotychczasową linię orzeczniczą w tej materii ${ }^{3}$.

O ile orzeczenie w glosowanej sprawie dotyczy konstytucyjności konkretnego aktu normatywnego, o tyle w świetle argumentacji TC zawartej w uzasadnieniu wyroku może i powinno być oceniane w kontekście specyfiki hiszpańskiego modelu ustroju terytorialnego, stanowiąc kolejną, koherentną z dotychczasowym orzecznictwem, wypowiedź tego sądu. Należy przy tym odnotować, że orzeczenia TC w tej materii mają szczególny ciężar gatunkowy z punktu widzenia trwania Królestwa Hiszpanii w dotychczasowych ramach ustrojowych, a także terytorialnych, budząc ogromne zainteresowanie tak w Hiszpanii, jak i na świecie, jako że tłem tych rozstrzygnięć są: zasada samostanowienia, prawo do secesji oraz zasada integralności terytorialnej.

Glosowany wyrok został wydany wskutek skargi wniesionej przez Prokuratora Generalnego w imieniu Przewodniczącego Rządu (nr skargi 4334-2017) przeciwko ustawie nr 19/2017, uchwalonej przez Parlament Katalonii w dniu 6 września 2017 r., zatytułowanej jako ustawa o referendum o samostanowieniu ${ }^{4}$. Stronami w sprawie były: Kongres Deputowanych, Senat oraz Parlament Katalonii, które jednak nie złożyły w sprawie żadnych pism procesowych, w tym stanowisk uczestników postępowania, aczkolwiek przedstawiciel Parlamentu Katalonii stawił się przez sądem.

2. Przedmiotowa ustawa regulowała przeprowadzenie wiążącego referendum w sprawie samostanowienia odnośnie do niepodległości Katalonii, a konsekwencje miały zależeć od wyniku referendum. Do najważniejszych przepisów ustawy,

2 Teza sformułowana na podstawie treści uzasadnienia.

3 M.in. orzeczenia STC 31/2010 z dnia 28 czerwca 2010 r. BOE nr 172, s. 11409 w sprawie Statutu Autonomicznego Katalonii, STC 42/2014, z dnia 25 marca 2014 r. BOE nr 87, s. 77 w sprawie deklaracji suwerenności i prawa do samostanowienia narodu katalońskiego. O dotychczasowym orzecznictwie zob. m.in. G. Marrero Gonzalez, Catalonia's Independence and the Role of the Constitutional Court: Recent Developments, "Tijdschrift voor Constitutioneel Recht" 2015, nr 86, s. 86-94; J. Joaquin Fernandez Alles, Spanish Constitutional Jurisprudence: Secession in Catalonia, "Journal of Comparative Law" 2018, vol. 13, nr 1, s. 179-203.

"Diari Oficial de la Generalitat The Catalunya" 2017, nr 7449A. 
do których odnosił się następnie w glosowanym wyroku TC, zaliczyć należy przede wszystkim art. 2, zgodnie z którym naród Katalonii jest suwerennym podmiotem politycznym i jako taki korzysta ze swojego prawa do swobodnego i demokratycznego decydowania o swojej sytuacji politycznej. Na uwagę zwraca również art. 3 ust. 1 ustawy, zgodnie z którym Parlament Katalonii miał działać jako organ przedstawicielski tak rozumianego suwerenna. $\mathrm{W}$ art. 3 ust. 2 ustawa ustanawiała wyjątkowy reżim prawny, mający na celu zarządzenie i przeprowadzenie referendum $\mathrm{w}$ sprawie samostanowienia Katalonii. Ustawa nadawała sobie hierarchiczną przewagę nad wszelkimi innymi przepisami, które byłyby z nią sprzeczne, co uzasadniała realizacją podstawowego i niezbywalnego prawa narodu Katalonii do samostanowienia. Ustawa $\mathrm{w}$ art. 4 ust. 2 przewidywała jednocześnie samo pytanie referendalne, które brzmiało: Czy chcesz, aby Katalonia była niepodległym państwem w formie republiki? W myśl ustawy wynik referendum miał mieć wiążący charakter (art. 4 ust. 3), co w przypadku odpowiedzi twierdzącej miało oznaczać niepodległość Katalonii i nakładać na Parlament Katalonii obowiązek, aby w terminie dwóch dni od ogłoszenia wyników przez Komisję Wyborczą zwołano zwyczajną sesję w celu wydania formalnej deklaracji niepodległości Katalonii (art. 4 ust. 4). W przypadku odpowiedzi negatywnej miało to oznaczać niezwłoczne rozpisanie wyborów do Parlamentu Katalonii. Na uwagę zwraca ponadto określony czas obowiązywania ustawy, jako że zgodnie z postanowieniami końcowymi jej przepisy miały przestać obowiązywać $\mathrm{z}$ chwilą ogłoszenia wyników referendum, z wyjątkiem postanowień artykułu 4, odnoszącego się do implementacji wyniku referendum.

Zaskarżona ustawa, która weszła w życie z chwilą jej oficjalnej publikacji, co miało miejsce jeszcze w dniu uchwalenia (6 września 2017 r.), następnego dnia została zawieszona na mocy decyzji TC, wydanej na podstawie art. 161 ust. 2 CE oraz art. 30 ustawy organicznej nr 2/1979 z 3 października 1979 r. o Trybunale Konstytucyjnym ${ }^{5}$.

3. W skardze złożonej przeciwko ustawie zarzucono jej niezgodność z konstytucją w całości, podnosząc, iż jest to spowodowane niekonstytucyjnością o charakterze materialnym, jak również kompetencyjnym oraz proceduralnym.

W zakresie materialnej niekonstytucyjności skarżący zarzucił ustawie, że regulując referendum w sprawie samostanowienia Katalonii, opiera się na suwerenności narodu katalońskiego, w którego imieniu miałby działać Parlament Katalonii. W związku z tym zaskarżona ustawa staje się najwyższym prawem, stawiając się poza oceną dokonywaną z punktu widzenia jej konstytucyjności. W rezultacie, zdaniem skarżącego, ustawa narusza wyrażoną w art. 1 ust. 2 CE zasadę suwerenności narodu

$5 \quad$ Na mocy kolejnych postanowień TC zawieszeniu uległo szereg aktów wykonujących postanowienia zaskarżonej ustawy, np. dotyczących zarządzenia referendum czy powołania członków Komisji Wyborczej. 
hiszpańskiego, wyrażoną w art. 2 CE zasadę nierozerwalnej jedności Narodu hiszpańskiego, rozumianej łącznie z zasadą uznania i zagwarantowania prawa do autonomii stanowiących go narodowości i regionów, oraz wyrażoną w art. $168 \mathrm{CE}$ procedurę zmiany konstytucji. W skardze podniesiono ponadto, że narusza to również art. 1 Statutu Autonomicznego Katalonii, zgodnie z którym Katalonia realizuje prawo do autonomii w ramach rzeczonego Statutu oraz Konstytucji. Zarzucono także naruszenie art. 22 tego Statutu, określającego tryb dokonywania jego zmiany. Odwołano się przy tym to standardów międzynarodowych w zakresie prawa do samostanowienia oraz zasady integralności terytorialnej oraz do orzecznictwa Sądu Najwyższego Kanady, Sądu Najwyższego Stanów Zjednoczonych, a także niemieckiego Federalnego Sądu Konstytucyjnego oraz włoskiego Sądu Konstytucyjnego. Ponadto, w zakresie skargi na poszczególne rozwiązania ustawy, odnoszące się do przeprowadzenia referendum, powołano standardy Komisji Weneckiej Rady Europy.

W zakresie zarzutu niekonstytucyjności o charakterze kompetencyjnym podniesiono, iż uchwalając skarżoną ustawę, zignorowano wyłączną kompetencję państwa w zakresie referendum konsultacyjnego, wynikającą z przepisów art. 149 ust. $1 \mathrm{CE}$ oraz art. $32 \mathrm{CE}$ w związku $\mathrm{z}$ art. 81 ust. $1 \mathrm{CE}$ oraz art. $2 \mathrm{CE}$, oraz usiłowano poddać pod taki rodzaj konsultacji fundamentalne kwestie odnoszące się do porządku konstytucyjnego, w sprawie których taki rodzaj konsultacji nie jest dopuszczalny, a właściwa jest jedynie procedura rewizji konstytucji, wskazana we wspomnianym art. 168 CE.

Ustawie postawiono ponadto zarzut niekonstytucyjności z powodu naruszeń proceduralnych, wskazując, że została ona uchwalona z naruszeniem trybu ustawodawczego, co Prokurator Generalny określił jako simulacrum (hiszp. simulacro) procedury legislacyjnej wykorzystanej przy jej uchwalaniu.

W związku z tym że - jak wspomniano - żadna ze stron postępowania przed TC nie złożyła w sprawie żadnych pism procesowych, wyliczone zarzuty niekonstytucyjności nie zostały zakwestionowane przez organy katalońskiego Generalitat.

4. Aprobata glosowanego wyroku skłania jednak do rozważenia kilku poruszanych zagadnień prawnych. Należy mieć przy tym na uwadze, że TC rozważał zaskarżoną ustawę jako ustanawiającą „wyjątkowy reżim prawny”, a także w kontekście jednoznacznie zadeklarowanej w jej preambule proklamacji suwerenności narodu katalońskiego, odrębnej od przewidzianej konstytucyjnie suwerenności narodu hiszpańskiego ${ }^{6}$. Stało się to ważnym kontekstem ustrojowym, po który TC sięgał wie-

6 O przypadku katalońskim w kontekście prawa do oporu patrz A.Romano, Constituent power and independence processes: problems and perspectives in the light of the Catalan experience, "Revista d'Estudis Autonòmics i Federals - Journal of Self-Government” 2018, nr 27, s. 49-52. 
lokrotnie $\mathrm{w}$ swoim orzeczeniu. Niestety TC nie uargumentował na płaszczyźnie materialnej, czemu odmawia Katalończykom statusu narodu ${ }^{7}$.

5. Jednym $\mathrm{z}$ kluczowych zagadnień prawnych związanych $\mathrm{z}$ ambicjami niepodległościowymi Katalonii jest oparte na standardach międzynarodowych prawo do samostanowienia, na które powołano się w preambule zaskarżonej ustawy. Co prawda preambuły nie są co do zasady przedmiotem oceny z punktu widzenia ich konstytucyjności, jednakże mogą służyć jako wskazówki interpretacyjne w poszukiwaniu intencji ustawodawcy ${ }^{8}$, w związku z czym TC uznał za właściwe odniesienie się do tych fragmentów wstępu do ustawy. Należy to uznać za słuszne i potrzebne z punktu widzenia ustosunkowania się do podnoszonych w sporze prawnym pomiędzy Katalonią i Madrytem argumentów, opierających katalońskie ambicje niepodległościowe na prawie do samostanowienia.

$\mathrm{W}$ orzeczeniu TC zwrócił słusznie uwagę, że CE nie uznaje, ani w preambule, ani w żadnym innym przepisie, prawa do samostanowienia w rozumieniu prawa jakiejkolwiek części narodu hiszpańskiego do jednostronnej secesji. Zasada ta nie jest też, zdaniem TC, częścią hiszpańskiego systemu prawnego poprzez wiążące Hiszpanię umowy międzynarodowe. Przyjęcie odmiennego założenia powodowałoby paradoksalną sytuację prawną, polegającą na tym, że państwo hiszpańskie, korzystając z własnej suwerenności państwowej, wiąże się tego rodzaju standardami międzynarodowymi, przez które właśnie wyzbywa się swojej suwerenności. Tego rodzaju umowy międzynarodowe stałyby tym samym w sprzeczności z konstytucją i jako takie wymagałyby uprzedniej zmiany CE (art. $75 \mathrm{CE}$ ). Można więc uznać, że zdaniem TC nie ma tym samym żadnych wiążących Hiszpanię standardów międzynarodowych, które wprowadzałyby do hiszpańskiego systemu prawnego prawo do jednostronnej secesji, ponieważ nie pozwala na to hiszpańska ustawa zasadnicza.

Niezależnie od tego TC odniósł się do międzynarodowych standardów w zakresie prawa do samostanowienia. Przyznając, że oba Międzynarodowe Pakty Praw Człowieka z dnia 19 grudnia 1966 r. deklarują prawo wszystkich ludzi do samostanowienia, przypomniał jednak, że w szeregu rozstrzygnięć, przyjętych w ramach systemu ONZ, ograniczono to prawo, które powinno być rozumiane jako jednostronny dostęp do niepodległości, ale możliwy w przypadkach „obcego ujarzmienia, do-

7 Patrz m.in. M. Weller, Secession and Self-Determination in Western Europe: The Case of Catalonia, (w:) Blog of the European Journal of International Law, publ. 18 października 2017, dwww.ejiltalk.org/secession-and-self-determination-in-western-europe-the-case-of-catalonia/\#more-15619 (10.01.2019), A. López-Basaguren, Claims for Secession in Catalonia. Rule of Law, Democratic Principle and Federal Alternative, (w:) A. López-Basaguren, L.E. San-Epifanio (red.), Claims for Secession and Federalism. A Comparative Study with a Special Focus on Spain, Cham 2019, s. 365-388, L. Che Ako, The Right To Self-Determination And Secession: Analysing The Catalonian Case, "Independent Student Journal: Law" 2018, nr 1, s. 11.

8 STC $104 / 2015 \mathrm{z}$ dnia 28 maja 2015 r., BOE nr 159, s. 55613, STC 170/2016 z dnia 6 października 2016 r., BOE nr 276, s. 79939. 
minacji i wyzysku"9. W uzasadnieniu orzeczenia zabrakło jednak odniesienia tych wskazówek do szerokich praw autonomicznych przysługujących Wspólnocie Autonomicznej Katalonii, umożliwiających realne decydowanie o sobie. Tym bardziej wykazałoby to brak możliwości oparcia się ustawodawcy katalońskiego na powoływanym standardzie międzynarodowym.

Ponadto TC przywołał Deklarację w sprawie przyznania niepodległości krajom i narodom kolonialnym z dnia 14 grudnia 1960 r., przyjętą Rezolucją Zgromadzenia Ogólnego ONZ 1514 (XV), zgodnie z którą każde działanie zmierzające do częściowego lub całkowitego naruszenia jedności narodowej i integralności terytorialnej państwa jest niezgodne z celami i zasadami Karty Narodów Zjednoczonych. Przywołano także potwierdzające takie rozumienie prawa do samostanowienia postanowienia Deklaracji z okazji pięćdziesiątej rocznicy powstania ONZ, zawarte w rezolucji Zgromadzenia Ogólnego 50/6 z dnia 24 października 1995 r., przy czym zwracano szczególną uwagę na zawarte tam stwierdzenie, iż prawa do samostanowienia nie należy interpretować jako zezwolenie lub zachęcanie do jakichkolwiek działań, które mogłyby unicestwić lub osłabić, w całości lub w części, integralność terytorialną lub polityczną jedność suwerennych i niepodległych państw, funkcjonujących w zgodzie z zasadą równych praw i samostanowienia, a zatem posiadających rząd reprezentujący całą ludność określonego terytorium bez jakiegokolwiek rozróżnienia. Zdaniem TC hiszpańska ustawa zasadnicza, kataloński Statut Autonomiczny, a także cały hiszpański system prawny zapewnia partycypację w hiszpańskim systemie rządów każdemu Hiszpanowi, a więc również każdemu Katalończykowi. Zasygnalizowano również, że troska o „tożsamość narodową”, o „podstawowe struktury polityczne i konstytucyjne” oraz o „integralność terytorialną" państw członkowskich, to zasady wyrażone wyraźnie w prawie europejskim o najwyższej mocy prawnej (art. 4 ust. 2 Traktatu o Unii Europejskiej). Zarysowane przez TC dominujące w prawie międzynarodowym rozumienie prawa do samostanowienia wyklucza, zdaniem TC, odniesienie tej zasady do sytuacji Katalonii. Niezrozumiałe jest jednak, dlaczego nie uznano za stosowne przywołać, wskazywane przecież przez skarżącego, orzeczenia sądów potwierdzające stanowisko TC ${ }^{10}$. Można odnieść wrażenie, że TC uznał, że jest ono tak oczywiste, iż nie potrzebuje kolejnych argumentów. Sąd nie odniósł się również do samego mechanizmu prawa do secesji, które w swym jednostronnym ujęciu generalnie nie ma zastosowania w państwach demokratycznych, w tym także w pań-

9 O zasadzie samostanowienia patrz m.in. A. Cassese, Self-Determination of Peoples: A Legal Reappraisal, Cambridge 1999; M. Perkowski, Samostanowienie narodów w prawie międzynarodowym, Warszawa 2001; J. Tyranowski, Integralność terytorialna, nienaruszalność granic i samostanowienie w prawie międzynarodowym, Warszawa-Poznań 1990.

10 Orzeczenia sądów innych państw, odnoszące sie do przedmiotowego zagadnienia, przywołuje A. Garrido-Muñoz, Prime Minister v. Parliament of Catalonia, „The American Journal Of International Law" 2018, vol. 112:1, s. 85-86. 
stwach o złożonej - federalnej lub regionalnej - strukturze terytorialnej ${ }^{11}$. W orzeczeniu zabrakło również uwzględnienia kazusu Kosowa ${ }^{12}$, który pozwoliłby z pewnością na bardziej wszechstronną argumentację, a przy ewentualnym dostrzeżeniu analogii w uwarunkowaniach faktycznych obu przypadków wykazanie, iż kazus Kosowa nie dostarcza argumentów przeciwnych stanowisku TC, stałoby się węzłową wypowiedzią jurydyczną w sporze prawnym pomiędzy Barceloną i Madrytem ${ }^{13}$. W kontekście istotnej z punktu widzenia prawa międzynarodowego zasady efektywności i mających nieraz kluczowe znaczenie dla przebiegu granic „faktów dokonanych” nie rozważono również prorosyjskiej argumentacji, używanej w przypadku Krymu, usiłującej przeciwstawić się dominującemu w doktrynie zachodniej „waszyngtońskiemu" postrzeganiu zasady samostanowienia ${ }^{14}$.

6. Kolejnym zagadnieniem prawnym, rozważanym przez TC, był zarzut braku kompetencji w zakresie referendum, naruszający tym samym wyłączną właściwość władz państwowych w odniesieniu do konsultacji ludowych w drodze referendum. W związku tym, że CE w art. 149 ust. 1 pkt 32 przewiduje, iż upoważnienie do zarządzania konsultacji ludowych w drodze referendum należy do wyłącznej kompetencji państwa, kwestia stwierdzenia niekonstytucyjności ustawy z tego powodu była dość oczywista, przy czym warto zauważyć, że zgodnie z utrwalonym orzecznictwem TC z powołanego przepisu CE wynika ekskluzywność nie tylko w zakresie samego zarzą-

11 Por. L. Brilmayer, Secession and Self-Determination: A Territorial Interpretation. Faculty Scholarship Series 1991, nr 16, s. 177-202, M. Milanovic, A Footnote on Secession. Blog of the European Journal of International Law 2017, www.ejiltalk.org/a-footnote-on-secession (1.10.2018).

12 Opinia MTS, "Accordance with International Law of the Unilateral Declaration of Independence in Respect of Kosovo", 2010 ICJ Rep. 403, para. 109; szerzej o tej opinii patrz m.in. Wilde R., Kosovo (Advisory Opinion), Max Planck Encyclopedia of Public International Law [MPEPIL], data publikacji: maj 2011.

13 Inaczej jednak uważa Asier Garrido-Muñoz, według którego powołanie się na kazus Kosowa w przypadku Katalonii nie wydaje się rozstrzygające w przypadku zastosowania do kontekstu katalońskiego z dwóch powodów. Zdaniem tego autora, po pierwsze, wątpliwe jest, aby rozumowanie MTS mogło mieć odniesienie do innych okoliczności poza rozpatrywanym przez ten sąd przypadkiem Kosowa. Po drugie, zasada efektywności jest dość problematyczna w odniesieniu do powstawania nowego państwa; A. Garrido-Muñoz, Prime Minister...op. cit., s. 86; inaczej N. Levrat, S. Antunes, G. Tusseau, P. Williams, Catalonia's Legitimate Right to Decide, Paths to Self-Determination, 2017, s. 67; d www.exteriors.gencat.cat/web/.content/00_ACTUALITAT/notes_context/FULL-REPORT-Catalonias-legitimate-right-to-decide.pdf (1.12.2018).

14 Por. Opinia Komisji Weneckiej, "Whether the Decision Taken by the Supreme Council of the Autonomous Republic of Crimea in Ukraine to Organise a Referendum on Becoming a Constituent Territory of the Russian Federation or Restoring Crimea's 1992 Constitution is Compatible with Constitutional Principles." Opinia z dnia 21 marca 2014, nr 762/2014, Doc. CDL-AD(2014)002; M. Perkowski, Forsowanie samostanowienia we współczesnej Europie. Uwagi na tle przypadków Krymu i Katalonii, (w:) M. Perkowski, J. Szymański, M. Zdanowicz (red.), Człowiek i prawo międzynarodowe. Księga dedykowana Profesorowi Bogdanowi Wierzbickiemu, Białystok 2014, s. $387 \mathrm{i} \mathrm{n}$. 
dzenia owych konsultacji, ale również w zakresie ustanawiania przepisów je regulujących, co powinno przybierać wyłącznie formę ustaw organicznych zgodnie z art. 81 ust. $1 \mathrm{CE}$ oraz z art. 92 ust. $3 \mathrm{CE}$. Na ocenę wyłączności państwa w tym zakresie nie wpływa również, zdaniem TC, kwestia zakresu terytorialnego spraw, których dane referendum ma dotyczyć ${ }^{15}$.

Takie stanowisko TC znajduje potwierdzenie w niedawnych orzeczeniach tego $\mathrm{sądu}^{16}$, który wielokrotnie podkreślał, że fundamentalne kwestie ustrojowe, rozstrzygnięte $\mathrm{w}$ określony sposób $\mathrm{w}$ ramach konstytucji, zostały tym samym wyłączone z właściwości władz publicznych i nie mogą podlegać konsultacjom ludowym, niezależnie od tego, czy miałoby to przybierać formę referendum, czy jakąkolwiek inną postać. Jedyną możliwą drogą do zmiany w tym zakresie jest zatem procedura zmiany konstytucji, przewidziana w art. $168 \mathrm{CE}$, przewidująca referendum w sprawie zmiany konstytucji. Potwierdza to tym samym stanowisko TC, zgodnie z którym wspólnota autonomiczna nie może zarządzać referendum, które wykraczałoby poza przyznane jej kompetencje, a tym bardziej referendum w sprawach, które zostały rozstrzygnięte na drodze decyzji ustrojodawczych ${ }^{17}$.

W świetle dość jednoznacznego brzmienia przepisów konstytucyjnych oraz utrwalonego orzecznictwa TC nie miał właściwie innego wyjścia, niż stanąć na straży wyłączności państwa w zakresie instytucji tego rodzaju referendum. Zarówno sama zaskarżona ustawa nie znajduje bowiem żadnej podstawy prawnej w hiszpańskim systemie konstytucyjnym, wykraczając poza właściwość ustawodawczą wspólnoty autonomicznej, jak i forma zarządzenia referendum jest wprost niezgodna z przepisem art. 149 ust. 1 pkt $32 \mathrm{CE}$, przewidującym, że upoważnienie do zarządzania konsultacji ludowych w drodze referendum należy do wyłącznej kompetencji państwa.

7. W zakresie badania konstytucyjności zaskarżonej ustawy na płaszczyźnie materialnej TC nie mógł mieć wątpliwości co do jej całkowitej i wręcz literalnej niezgodności z podstawowymi, pozostającymi ze sobą w związku zasadami hiszpańskiego systemu konstytucyjnego: suwerenności narodu hiszpańskiego (art. 1 ust. 2 CE), nierozerwalnej jedności Narodu hiszpańskiego (art. 2 CE), socjalnego i demokratycznego państwa prawnego (art. 1 ust. 1 CE) oraz zwierzchnictwa konstytucji (art. 9 ust. $1 \mathrm{CE})$.

15 STC 31/2015 z dnia 25 lutego 2015 r., BOE nr 64, s. 190; inaczej A. Romano, Constituent power and independence processes: problems and perspectives in the light of the Catalan experience, "Revista d'Estudis Autonòmics i Federals - Journal of Self-Government" 2018, nr 27, s. 68- 69.

16 STC 51/2017 z dnia 10 maja 2017 r., BOE nr 142, s. 49386, a także inne przywoływane tam wcześniejsze orzeczenia.

17 STC 103/2008 z dnia 11 września 2008 r., BOE nr 245 (suplement), s. 3, STC 138/2015 z dnia 11 czerwca 2015 r., BOE nr 160, s. 56313; J.M. Castellà Andreu, Constitution and Referendum on Secession in Catalonia, (w:) A. López-Basaguren, L.E. San-Epifanio (red.), Claims for Secession and Federalism. A Comparative Study with a Special Focus on Spain, Cham 2019, s. 405-422. 
Zdaniem TC naruszenie konstytucji jest na tyle bezpośrednie i intensywne, że można je uznać za całkowite odrzucenie wiążącej mocy samej konstytucji, która została uznana za sprzeczną z władzą uzurpującą sobie suwerenność i ustanawiającą wymiar konstytucyjny, z którego w sposób rażący odrzuca obowiązujący system konstytucyjny. Jest tym samym afirmacją władzy, która rości sobie prawo do utworzenia nowego ustroju politycznego i z tego powodu czuje się zwolniona $\mathrm{z}$ wszelkich więzi prawnych.

Nie można nie zgodzić się z twierdzeniem TC, że postanowienie ustawy „o hierarchicznej przewadze nad wszelkimi innymi przepisami, które mogą wejść z nią w konflikt” (art. 3 ust. 2) narusza zasadę zwierzchnictwa konstytucji. Dość oczywiste stanowisko TC znajduje swoje oparcie w zasadzie demokratycznego państwa prawnego, której utrwalonym elementem jest zasada hierarchicznego systemu źródeł prawa, zgodnie z którą żaden organ władzy publicznej ani żaden rodzaj aktu normatywnego nie może samodzielnie i jednostronnie decydować o obowiązywaniu lub stosowaniu aktów normatywnych o wyższej mocy prawnej, a w szczególności o konstytucji. Sprzeczne z tą zasadą jest więc jakiekolwiek uzależnianie obowiązywania norm wyższej mocy prawnej od ich niesprzeczności z zaskarżoną ustawą. Odnosi się to także do zignorowania Statutu Autonomicznego Katalonii, co TC również słusznie wytknął w swoim orzeczeniu. Zawarte w postanowieniach końcowych ustawy stwierdzenie, iż „normy państwa hiszpańskiego mają swoje zastosowanie, o ile nie są sprzeczne $z$ ustawą”, jest tak bezpośrednim naruszeniem konstytucyjnej hierarchii aktów prawnych, że TC nawet nie usiłował szerzej uzasadniać swojego stanowiska w tym zakresie.

Trybunał Konstytucyjny nie mógł zaakceptować również postanowienia zawartego w art. 2 zaskarżonej ustawy, zgodnie z którym naród Katalonii jest suwerennym podmiotem politycznym, w związku z czym realizuje swoje prawo do wolnego i demokratycznego decydowania o swojej sytuacji politycznej. Norma ta jest bowiem wyraźnie sprzeczna z art. 1 ust. $2 \mathrm{CE}$, zgodnie z którym suwerenność narodowa należy do narodu hiszpańskiego. Przywołując swoje orzecznictwo ${ }^{18}$, TC przypomniał, że ani mieszkańcy Katalonii nie posiadają suwerennej władzy, która należy wyłącznie do narodu hiszpańskiego, ani nie powinni być w związku z tym identyfikowani jako podmiot prawny, który konkuruje z konstytucyjnie określonym suwerenem. W związku z tym TC jednoznacznie, po raz kolejny, odmówił obywatelom Katalonii statusu suwerennego narodu, rozumianego jako źródło władzy konstytucyjnej, a także odrzucił zawartą w preambule do ustawy próbę oparcia legitymizacji suwerenności katalońskiej na „naruszeniu hiszpańskiego paktu konstytucyjnego z 1978 r., argumentując że konstytucja nie jest wynikiem porozumienia między „instytucjami terytorialnymi”, które zachowują pewne prawa pierwotne i nadrzędne względem 
konstytucji, ale jest aktem prawnym, narzucającym wiążącą moc w swoim zakresie i uznającym cały naród hiszpański za źródło wszelkiej władzy ${ }^{19}$.

W swoim orzeczeniu TC odniósł się również do samej idei regulowanego przez ustawę „wiążącego referendum w sprawie samostanowienia", nie mając żadnych wątpliwości, że jako wynikające z niekonstytucyjnego założenia o „suwerenności narodu Katalonii" jest nie do pogodzenia z zasadą jedności narodu hiszpańskiego, na której opiera się konstytucja (art. 2 CE). Słusznie TC uznał, że co prawda samo ustalenie wyników takiego referendum nie implikowałoby niepodległości Katalonii, to jednak oznaczałoby odrzucenie jedności Narodu i państwa na tej jedności ustanowionego. $Z$ argumentacji przedstawionej przez TC wyłania się stanowisko sądu, zgodnie z którym sam byt prawny instytucji referendum tego rodzaju w hiszpańskim systemie prawnym jest zagrożeniem ładu konstytucyjnego, ponieważ niezależnie od tego, czy takie referendum miałoby być przeprowadzone, a także niezależnie od jego wyników, oznaczałoby tolerowanie w hiszpańskim porządku konstytucyjnym instytucji, która potencjalnie mogłaby prowadzić do skutków prawnych sprzecznych z zasadą jedności narodu hiszpańskiego, na co TC nie może w żadnym przypadku pozwolić. W orzeczeniu zwrócono także uwagę na niedopuszczalność tak ukształtowanego referendum z punktu widzenia niekonstytucyjności ograniczenia kręgu osób uprawnionych do wzięcia udziału w takiej konsultacji, jako że zgodnie z zaskarżoną ustawą udział byłby zastrzeżony tylko dla części narodu hiszpańskiego. W związku z tym, że przedmiot referendum dotyczyłby trwałości wspólnego państwa, rozstrzygnięcia $\mathrm{w}$ tego rodzaju sprawach powinny być, $\mathrm{w}$ razie potrzeby, podejmowane przez wszystkich Hiszpanów ${ }^{20}$.

Warto jednak zwrócić uwagę na tezę odnoszącą się do możliwości całkowitej zmiany konstytucji. Zdaniem TC wszystkie przepisy konstytucji podlegają ewentualnym zmianom, a suweren ma pełnię władzy w zakresie dowolnego modyfikowania ich treści. Pełna otwartość na rewizję oznacza także możliwość uwzględnienia takich koncepcji ideologicznych, które polegałyby na uznaniu określonej grupy za społeczność narodową ${ }^{21}$. Jednak TC zastrzega, że może się to odbywać wyłącznie na drodze procedury zmiany konstytucji, gdyż gdyby przyjąć inne założenie, powodowałoby to uwolnienie władz publicznych z obowiązku przestrzegania konstytucji, co zdaniem TC miało właśnie miejsce w odniesieniu do Parlamentu Katalonii i kwestionowanej ustawy.

19 W ten sposób także TC argumentował w orzeczeniu STC 42/2014 z dnia 25 marca 2014 r., BOE nr 87, s. 77.

20 STC 90/2017 z dnia 5 lipca 2017 r., BOE nr 171, s. 63290.

21 G.C. Villar Federal Reform of Spain vs Secession in Catalonia. Could Constitutional Reform Provide a Response to the Demands Upon Which the Justification for Secession Are Based?, (w:) A. López-Basaguren, L.E. San-Epifanio (red.), Claims for Secession and Federalism. A Comparative Study with a Special Focus on Spain, Cham 2019, s. 443-459. 
Trybunał Konstytucyjny podkreślił ponadto, że Parlament Katalonii, uchwalając zaskarżoną ustawę, wystąpił przeciwko zasadzie suwerenności narodu, oddającej władzę zwierzchnią w ręce całego Narodu hiszpańskiego, poprzez wezwanie tylko jego części do decydowania o losie całego państwa, usiłując w ten sposób zignorować wynikający z obowiązującego porządku prawnego status ustrojowy wspólnoty autonomicznej, naruszając tym samym zarówno konstytucyjną zasadę prawa do autonomii (art. 2 CE), jak i sam Statut Autonomiczny Katalonii (art. 1, art. 2). W orzeczeniu TC przypomniał formułowaną już wcześniej koncepcję lojalności konstytucyjnej, obowiązującej wszystkie podmioty jej podległe ${ }^{22}$.

Zdaniem TC Parlament Katalonii, uchwalając zaskarżoną ustawę, de facto anulował na terytorium Katalonii ważność Konstytucji, Statutu Autonomicznego i wszelkich innych norm prawa, które byłyby sprzeczne $\mathrm{z}$ ustawą, co przybrało formę działań „apodyktycznych”, przyznających sobie prawo do działania jako przedstawiciel "nieistniejącego prawnie suwerena” oraz prawo do wydawania według własnego uznania norm o najwyższej mocy prawnej. Parlament Katalonii działał więc w zupełności w sprzeczności z zasadą rządów prawa, otwarcie zaprzestając działania w ramach swoich własnych uprawnień konstytucyjnych i ustawowych, narażając w ten sposób ważność i skuteczność wszelkich praw i środków ochrony obywateli Katalonii przewidzianych w Konstytucji i zapewnianych przez państwo. W ten sposób Katalończycy, zdaniem TC, zostali pozostawieni na łasce władzy, która nie uznaje żadnego limitu. Poprzez wprowadzenie „wyjątkowego porządku prawnego" (art. 3 ust. 2 ustawy) Parlament Katalonii odrzucił tym samym wymagania rządów prawa, które polegają na zapewnieniu, że ich władze publiczne są sługami, a nie właścicielami prawa. Parlament Katalonii takim działaniem naruszył ponadto zasadę demokracji poprzez odmowę podporządkowania się Konstytucji, co jest formą podporządkowania się woli narodu, objawiającej się w tym przypadku jako władza ustrojodawcza, która należy do całego narodu hiszpańskiego, a nie do jednej jego części. Odniósł się także do mandatu demokratycznego Parlamentu Katalonii ${ }^{23}$, przypominając, że może być realizowany wyłącznie na drodze środków przewidzianych prawem. Podzielając stanowisko TC, można dodać, że mieszkańcy Katalonii, udzielając w wyborach z 27 września 2015 r. stosownej legitymacji organowi przedstawicielskiemu,

22 SSTC 181/1988 z dnia 13 października 1988 r., BOE nr 266 (suplement), s. 22, STC 9/2017 z dnia 19 stycznia 2017 r., BOE nr 46, s. 1892; L. Álvarez, Territorial Secession and Federal Loyalty in the 1978 Spanish Constitution, (w:) A. López-Basaguren, L.E. San-Epifanio (red.), Claims for Secession and Federalism. A Comparative Study with a Special Focus on Spain, Cham 2019 s. 543- 561.

23 Asier Garrido-Muñoz zwraca uwagę na fakt, że sama reprezentatywność władz Katalonii w tym zakresie może być kontestowana w kontekście wyniku wyborczego, jako że na podejmującą w przedmiotowej sprawie decyzje większość parlamentarną wcale nie głosowała większość Katalończyków. Na formacje proniepodległościowe w wyborach z 27 września 2015 r. oddano bowiem 47,74\% ważnie oddanych głosów, co przełożyło się na 72 mandaty, przy 135 mandatach ogółem;

A. Garrido-Muñoz, Prime Minister..., op. cit., s. 87. 
powierzyli mu realizowanie określonego programu politycznego, ale choćby jego realizacja miała zmierzać do zmiany statusu politycznego Katalonii, udzielony mandat upoważnia wyłącznie do działań w zakresie instrumentarium dostępnego w ramach obowiązującego porządku prawnego.

8. Poza omówionymi wyżej naruszeniami o charakterze kompetencyjnym oraz materialnoprawnym TC ustosunkował się również do kwestii formalnoprawnych, związanych z procedurą uchwalania zaskarżonej ustawy. Warto przy tym zauważyć, że hiszpański TC na mocy art. 39 ust. 2 ustawy organicznej o Trybunale Konstytucyjnym nie jest związany granicami skargi i może stwierdzić niekonstytucyjność z powodu naruszenia jakiegokolwiek przepisu konstytucyjnego, niezależnie od tego, czy zostało to podniesione $\mathrm{w}$ toku postępowania.

$\mathrm{W}$ toku analizy postępowania ustawodawczego, którego efektem było uchwalenie zaskarżonej ustawy, TC ustalił, że doszło do szeregu naruszeń proceduralnych, które polegały na nieregulaminowej zmianie porządku posiedzenia, (m.in. uniemożliwiającej zachowanie okresu dwóch dni na zapoznanie się z projektem ustawy), na nieuwzględnieniu wielokrotnie wnoszonego wniosku o zasięgnięcie opinii Rady Gwarancji Ustawowych, która działając na podstawie Statutu Autonomicznego Katalonii, ma zabezpieczać przed uchwaleniem prawa niezgodnego $\mathrm{z}$ hiszpańskim blokiem konstytucyjnym, ale przede wszystkim na procedowaniu ustawy $\mathrm{w}$ trybie nieznanym regulaminowi. Procedowano bowiem w oparciu o wolę większości parlamentarnej, która ad hoc podejmowała decyzje odnośnie kształtu procedury legislacyjnej, uznaniowo dopuszczając lub ograniczając prawa pozostałych deputowanych. Zdaniem TC najistotniejszym naruszeniem konstytucji stało się właśnie podporządkowanie zasady rządów prawa woli większości. Odnosząc się do naruszenia praw deputowanych, TC przypomniał, że powinno ono być realizowane jako wynikające z zasady rządów prawa, a nie kurtuazji większości ${ }^{24}$. Zarówno w skardze, jak i samym orzeczeniu, pojawił się termin określający taki sposób procedowania w sprawie ustawy - simulacrum - rozumiany jako określenie procedury, która stwarzając pozory postępowania zgodnego $\mathrm{z}$ regulaminem, nie znajduje jednak w nim oparcia de iure. Ocena procedury uchwalania ustawy pozostawała pod wpływem ukształtowanej $\mathrm{w}$ orzecznictwie TC tezy ${ }^{25}$, zgodnie $\mathrm{z}$ którą nieprzestrzeganie przepisów regulujących postępowanie legislacyjne może prowadzić do niekonstytucyjności tak uchwalonego prawa, gdy wpłynęło to w znaczący sposób na proces kształtowania się woli w danej izbie, a w szczególności gdy zasady postępowania zostały potraktowane w sposób instrumentalny, naruszając zasadę pluralizmu politycznego, która jest podstawową wartością całego hiszpańskiego systemu prawnego (art. 1 ust. $1 \mathrm{CE}$ ).

24 STC 109/2016, z dnia 6 czerwca 2016 r., BOE nr 170, s. 50113.

25 Patrz m.in. STC 215/2016 z dnia 15 grudnia 2016 r., BOE nr 17, s. 5302 oraz wskazane tam poprzednie orzeczenia. 
Poszanowanie zasady pluralizmu politycznego powinno być zatem, zdaniem TC, odczytywane w kontekście poszanowania praw opozycji oraz równego dla wszystkich deputowanych prawa do realizacji mandatu przedstawicielskiego.

Uznając wolę organu przedstawicielskiego za wartość chronioną konstytucyjnie, TC uznał, że jest ona legitymizowana jednak tylko wtedy, gdy przestrzegane są reguły proceduralne. $Z$ aprobatą należy odnieść się szczególnie do wypływającej ze stanowiska TC konkluzji, że nie każde naruszenie procedury jest podstawą uznania niekonstytucyjności danego aktu prawnego, a tylko takie uchybienie, które skutkuje naruszeniami wartości konstytucyjnych.

9. Biorąc pod uwagę dotychczasowe orzeczenia TC, można odnieść wrażenie, że ustawodawca kataloński do tej pory usiłował pozorować rozpoczęcie procesu secesji od aktualnej lokacji ustrojowej Katalonii w ramach państwa hiszpańskiego. Tym razem zaskarżoną ustawą podjęto próbę odizolowania się od hiszpańskiego systemu ustrojowego, wskazując ustawą odrębne źródło legitymizacji władzy i samej ustawy jako jej owocu. Nawiązanie do standardów międzynarodowych miało wskazać, że Katalonia czuje się członkiem i podmiotem wspólnoty międzynarodowej, a swój proces niepodległościowy usiłuje oprzeć na zasadzie samostanowienia. Natomiast nawiązanie do przepisów hiszpańskiego systemu konstytucyjnego, z zastrzeżeniem, że przepisy prawa hiszpańskiego nie mogą być stosowane, jeśli miałyby być sprzeczne $\mathrm{z}$ ustawą, wydaje się, że można oceniać jako wskazanie systemu prawnego, z którego Katalonia rozpoczyna secesję.

Orzeczenie TC skłania do wniosku, że zważywszy na niemożliwą do pogodzenia z hiszpańską ustawą zasadniczą secesją którejkolwiek ze wspólnot autonomicznych, będzie to w przypadku każdej tego rodzaju próby skutkowało kolejnym orzeczeniem o niekonstytucyjności aktów podejmowanych $\mathrm{w}$ ramach tego procesu ${ }^{26}$. W świetle stanowiska TC zawartego tak w glosowanym, jak i w poprzednich - wspomnianych powyżej - orzeczeniach, można sformułować konkluzję, że nie jest to możliwe bez uprzedniej zmiany hiszpańskiego porządku konstytucyjnego ${ }^{27}$.

Sama ustawa, zarówno w zakresie jej treści, procedury jej uchwalania, jak i kompetencji do jej uchwalenia, właściwie nie dawała innej możliwości TC. Niekonstytucyjność była dość oczywista i można zakładać, że zdawał sobie z tego sprawę sam kataloński ustawodawca, który szukał innej legitymacji niż hiszpańska konstytu-

26 C. Plaza, Catalonia's Secession Process at the Constitutional Court: A Never-Ending Story, "European Public Law" 2018, vol. 24(3), s. 373-392.

27 B. Aláez Corral, F.J. Bastida Freijedo, Constitutionalizing Secession in Order to Harmonize Constitutionality and Democracy in Territorial Decentralized States Like Spain, (w:) A. López-Basaguren, L.E. San-Epifanio (red.), Claims for Secession and Federalism. A Comparative Study with a Special Focus on Spain, Cham 2019, s. 265-285. Różne scenariusze dla Katalonii i Hiszpanii kreśli J. Oskam, A new state in Europe? Scenarios for Catalan self-determination, Futures 2014, nr 64, s. 51-60. 
cja, wręcz demonstracyjnie ją naruszając. Co bowiem znamienne, sama zaskarżona ustawa nie znajduje i nie wskazuje bowiem żadnej podstawy prawnej w hiszpańskim systemie konstytucyjnym, bazując domyślnie na suwerenności narodu Katalonii. Było wielce prawdopodobne, że TC, oceniając przez pryzmat zaskarżonej ustawy niepodległościowe aspiracje katalońskie, będzie to robił w ramach gorsetu konstytucyjnego, w związku z czym trudno było oczekiwać od sądu konstytucyjnego, aby priorytetowo odniósł się do woli politycznej Katalończyków kosztem hiszpańskiego porządku konstytucyjnego, na straży którego stoi. 